\title{
PENERAPAN PEMBELAJARAN BRAINSTORMING DENGAN \\ PENDEKATAN SUPERVISI KLINIS DALAM MENINGKATKAN KETERAMPILAN DASAR MENGAJAR PADA MATA KULIAH MICRO TEACHING KELAS C SEMESTER VI PGPAUD UNDIKSHA
}

\author{
I Wayan Sujana \\ Jurusan Pendidikan Guru Sekolah Dasar, Universitas Pendidikan Ganesha \\ Email: sujanawyn59@gmail.com
}

\begin{abstract}
ABSTRAK
Penelitian ini bertujuan untuk meningkatkan keterampilan mengajar melalui penerapan pembelajaran brainstorming dengan pendekatan supervisi klinis pada mata kuliah micro teaching kelas C Semester VI PGPAUD Undiksha. Adapun subjek dalam penelitian ini adalah mahasiswa semester VI PGPAUD UPP Denpasar yang berjumlah 18 orang mahasiswa. Data dikumpulkan melalui teknik non-tes menggunakan lembar observasi, dan dianalisis dengan teknik statistik deskriptif kuantitatif. Hasil yang diperoleh dari tahap prasiklus dengan persentase keterampilan dasar mengajar sebesar 80,56\%, terjadi peningkatan pada siklus I menjadi $85,94 \%$ dan pada siklus II terjadi peningkatan menjadi $86,5 \%$. Persentase tersebut telah berada pada kategori sangat tinggi. Dari hasil persentase tersebut dapat disimpulkan bahwa penerapan pembelajaran brainstorming dengan pendekatan supervisi klinis dapat meningkatkan keterampilan dasar mengajar pada mata kuliah micro teaching Kelas C Semester VI PGPAUD Undiksha
\end{abstract}

Kata kunci : Brainstorming, Micro teaching, Keterampilan mengajar.

\section{ABSTRACT}

This study purpose to improve teaching skills through the application of brainstorming learning with a clinical supervision approach in the micro teaching class $C$ Semester VI PGPAUD Undiksha. The subjects in this study are sixth semester students PGPAUD UPP Denpasar, amounting to 18 students. Data were collected by non-test techniques using observation sheets, and analyzed by quantitative descriptive statistical techniques. Results obtained from pre cycle stage with the percentage of basic teaching skill of $80.56 \%$, an increase in the first cycle to $85.94 \%$ and in the second cycle there was an increase to $86.5 \%$. The percentage is already in very high category. From the results of the percentage can be concluded that with the application of brainstorming learning with clinical supervision approach can improve the basic skills of teaching in micro teaching courses Class $C$ Semester VI PGPAUD Undiksha

Keywords: Brainstorming, Micro teaching, Teaching skills.

\section{PENDAHULUAN}

Peningkatan profesionalisme guru terkait dengan peningkatan kompetensi guru yang meliputi kompetensi pedagogik, professional, sosial, dan personal. Mahasiswa pendidikan guru anak usia dini atau PGPAUD, sesuai dengan kurikulum tahun 2012 pada semester VI ada program mata kuliah micro teaching. Pada micro teaching ini, mahasiswa calon guru dilatih mengenai delapan keterampilan dasar mengajar untuk dipahami dan nantinya secara utuh dapat diaplikasikan dalam proses pembelajaran di kelas, mana kala 
sudah menjadi guru. Adapun delapan keterampilan dasar mengajar tesebut meliputi (1) keterampilan dasar bertanya,

(2) keterampilan memberikan penguatan,

(3) keterampilan dasar menjelaskan, (4) keterampilan dasar mengadakan variasi, (5) keterampilan dasar membuka dan menutup pembelajaran, (6) keterampilan dasar mengelola kelas, (7) keterampilan dasar membimbing kelompok kecil, dan (8) keterampilan mengajar perseorangan.

Pada mata kuliah micro teaching, mahasiswa calon guru dilatihkan tentang keterampilan dasar mengajar secara terpisah dalam kurun waktu satu semester. Mahasiswa tersebut melatih diri untuk menguasi masing-masing keterampilan dasar mengajar dalam durasi waktu 10 hingga 12 menit. Tujuan dari micro teaching adalah untuk mempersiapkan mahasiswa calon guru membelajarkan siswanya degan efektif dan efisien, sehingga pembelajaran dapat berhasil, seperti pendapat Suyatno (2009) yang menyatakan bahwa ikatan emosi, empati, dan saling ketergantungan antara siswa dan guru terjadi memunculkan dimensi keberhasilan belajar.

Untuk pencapaian pembelajaran yang efektif maka ditempuh suatu cara melalui pemilihan strategi pembelajaran, yakni strategi brainstorming.

Brainstorming atau dikenal dengan curah pendapat atau sumbang saran merupakan suatu bentuk diskusi dalam rangka menghimpun gagasan, pendapat, informasi, pengetahuan, pengalaman, dari semua peserta (Sutikno, 2007). Dalam hal ini brainstorming memberikan kesempatan mahasiswa calon guru PAUD untuk menyumbangkan ide atau gagasan, saran, pendapat yang ditampung kemudian dijadikan suatu pengalaman belajar, diharapkan dari masing-masing mahasiswa memberikan masukan dan saran harus sesuai dengan jenis keterampilan yang dipraktekkan oleh mahasiswa memgenai keterampilan dasar mengajar yang ditugaskan. Posisi pembimbing dalam hal ini adalah (1) terkait dengan kegiatan yang memotivasi, (2) membimbing, dan (3) mengklarifikasi. Semakin banyak masukkan yang diberikan oleh msingmasing peserta terkait dengan kelebihan dan kekurangan, maka semakin banyak terjadi proses belajar dengan bertambahnya pengalaman belajar dari setiap masukan dan saran antar mahasiswa calon guru, yang berdampak pada kualitas keterampilan mengajar nanti di kelas pada saat mengajar secara utuh.

Kelebihan dan kelemahan yang dirasakan baik oleh calon guru dan masukan dari rekan sejawatnya, maka perlu diupayakan melalui pendekatan supervisi klinis. Suhartati (2014) "supervisi klinis adalah suatu proses bimbingan dalam pendidikan yang bertujuan untuk membina profesional guru dalam pengenalan mengajar melalui observasi dan analisis secara obyektif, teliti sebagai dasar perilaku untuk mengubah perilaku guru khususnya dalam penampilan mengajar" Sejalan dengan Suhartati, menurut Sudrajat (2008) supervisi klinis adalah "supervisi yang difokuskan pada perbaikan pembelajaran melalui siklus yang sistematis mulai dari tahap perencanaan, pengamatan dan analisis yang intensif terhadap penampilan pembelajarannya dengan tujuan untuk memperbaiki proses pembelajaran". Lebih lanjut Sudrajat mengatakan supervisi klinis memiliki beberapa tujuan seperti menciptakan kesadaran guru, memperbaiki kualitas proses pembelajaran, mengidentifikasi dan menganalisis masalah pembelajaran, menemukan cara pemecahan masalah dan mengembangkan sikap positif 
dalam mengembangkan diri secara berkelanjutan. Jika dikaitkan dalam pelaksanaan micro teaching dengan brainstorming, dan supervisi klinis memiliki tujuan sebagai berikut menciptakan kesadaran mahasiswa calon guru secara utuh tentang tanggung jawabnya terhadap pelaksanaan kualitas proses pembelajaran, (2) membantu mahasiswa calon guru untuk melatih, memperbaiki, dan meningkatkan kualitas proses pembelajaran yang sedang dilatihkan pada micro teaching, (3) mahasiswa calon guru turut serta untuk mengidentifikasi serta menganalisis kekurangan yang muncul selama praktek micro teaching, (4) mahasiswa calon guru turut serta untuk memberikan saran, gagasan, dan masukan untuk memperbaiki kekurangan yang muncul selama praktek micro teaching, dan (5) mahasiswa calon guru turut serta untuk mengembangkan sikap positif dalam diri untuk mendedikasikan diri pada pendidikan.

Melalui supervisi klinis, terjadi proses analisis mengenai apa yang dilakukan mahasiswa calon guru tentang proses belajarnya. Dalam hal ini dapat dikemukakan mengenai kelebihan dan kekurangan apa yang sudah dilakukan pada saat mempraktekkan masing-masing keterampilan dasar mengajar. Setelah mahasiswa mempraktekkan masing-masing keterampilan dasar mengajar dilanjutkan dengan proses mengintegrasikan kedelapan keterampilan dasar mengajar menjadi satu kesatuan yang utuh, yang kemunculannya menjadi kesatuan dalam proses pembelajaran. Melalui penerapan strategi pembelajaran brainstorming dengan pendekatan supervsi klinis para mahasiswa dapat semakin meningkat penguasaannya baik menyangkut apa yang harus dilakukan maupun apa yang harus dihindari dalam proses pembelajaran.

Berdasarkan hasil pengamatan dari hasil pelaksanaan praktek pengalaman lapangan, banyak guru-guru yang belum menerapkan kedelapan keterampilan mengajar secara utuh dan terintegrasi. Disamping itu munculnya kebosanan anakanak TK dalam meningikuti pembelajaran, hal itu ditunjukkan dari perhatian anak dalam belajar yang kurang serius, anakanak kurang memperhatikan guru, termasuk juga anak-anak kurang tertarik dengan media yang dipergunakan guru.

\section{METODE}

Metode pelaksanaan penelitian ini adalah PTK meliputi empat tahapan yaitu perencanaan, pelaksanaan, observasi dan refleksi dengan pendekatan supervisi klinis. Kegiatan tersebut dapat dijelaskan sebagai berikut.

\section{Perencanaan}

Tahap perencanaan ini termasuk dalam tahap perencanaan awal pada supervisi klinis ini diawali dengan melakukan koordinasi dengan ketua UPP untuk melakukan penelitian. Setelah mendapatkan izin, dilanjutkan dengan melakukan refleksi awal dengan melihat tingkat kemampuan mempraktekkan keterampilan mengajar pada micro teaching sebelum melakukan penelitian. Kemudian melakukan analisis kurikulum pada mata kuliah micro teaching, mempersiapkan rencana pembelajaran melalui penerapan pembelajaran brainstorming dengan pendekatan supervisi klinis pada satuan acara perkuliahan (SAP), serta menyusun lembar observasi alat penilaian kemampuan calon guru-2 (APKCG-2) yang digunakan mengobservasi mahasiswa untuk mendapatkan data riil. 


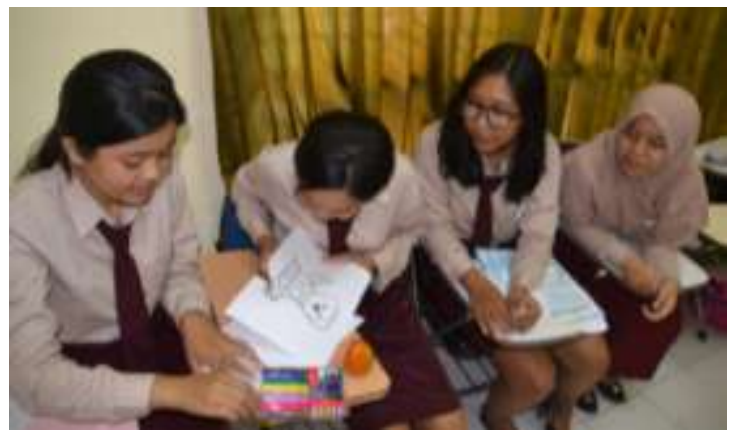

Gambar 1. Tahap persiapan mendiskusikan RPPH yang akan dipraktekkan

\section{Pelaksanaan}

Pelaksanaan penelitian ini disusun dengan tahapan sesuai dengan kegiatan micro teaching di Undiksha PGPAUD UPP Denpasar. Tahap ini termasuk pada

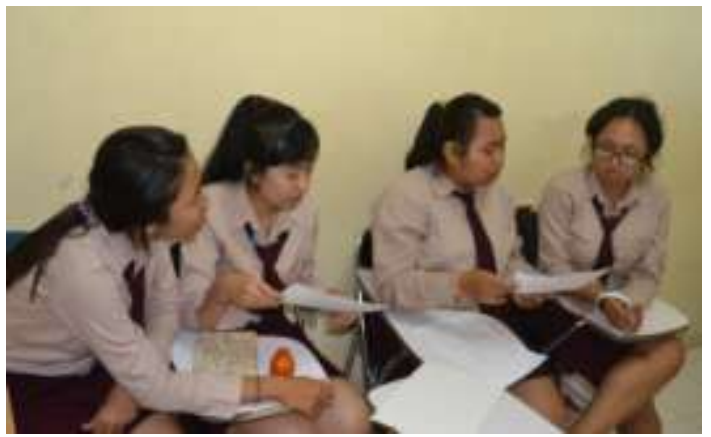

tahap pelaksanaan mengajar dengan pendekatan supervisi klinis. Setiap siklus penelitian terdiri dari 3 kali pertemuan, yang disertai evaluasi menggunaan lembar observasi APKCG-2 pada mahasiswa.
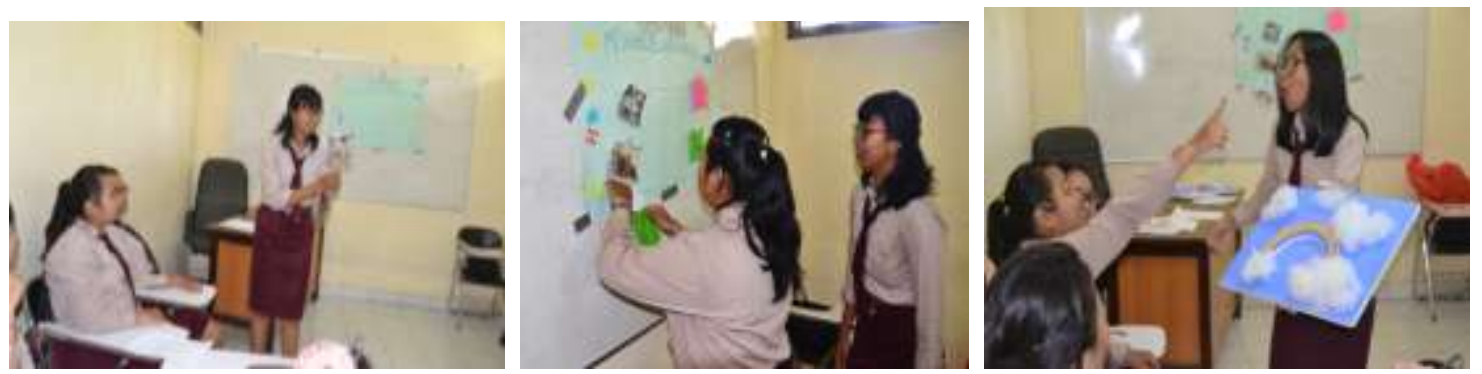

Gambar 2. Tahap pelaksanaan tindakan, dengan memptaktekkan RPPH yang telah didiskusikan.

Observasi

Tahap ini juga termasuk pada tahap pelaksanaan observasi pada supervisi klinis. Pada tahap observasi, yang dilakukan adalah mengamati pelaksanaan pembelajaran dengan menggunakan lembar observasi yang dibuat sesuai dengan keterampilan dasar mengajar yang dikontrakkan dari delapan keterampilan dasar mengajar yang ada. Setiap kejadian dicatat pada lembar observasi dan dicatat juga tentang apa yang menjadi kelebihan dan kelemahan pada setiap keterampilan dasar mengajar sehingga pembelajaran brainstorming dapat berlangsung dengan baik serta secara jelas terlihat hal yang perlu ditingkatkan dan dipertahankan serta hal-hal apa yang tidak boleh dilakukan selama kegiatan pembelajaran berlangsung. Observasi juga dilakukan saat kegiatan pembelajaran micro teaching memasuki tahap akhir atau diskusi balikan dengan pendekatan supervisi klinis.

\section{Refleksi}

Refleksi ini dilakukan untuk memantau dan mengkaji hasil tindakan disetiap siklus pada mata kuliah micro teaching. Hasil kajian tiap siklus ini selanjutnya direncanakan untuk mencari alternatif tindakan baru yang lebih efektif untuk meningkatkan keterampilan mengajar dengan mengefektifkan pembelajaran brainstorming dengan pendekatan supervisi klinis. 

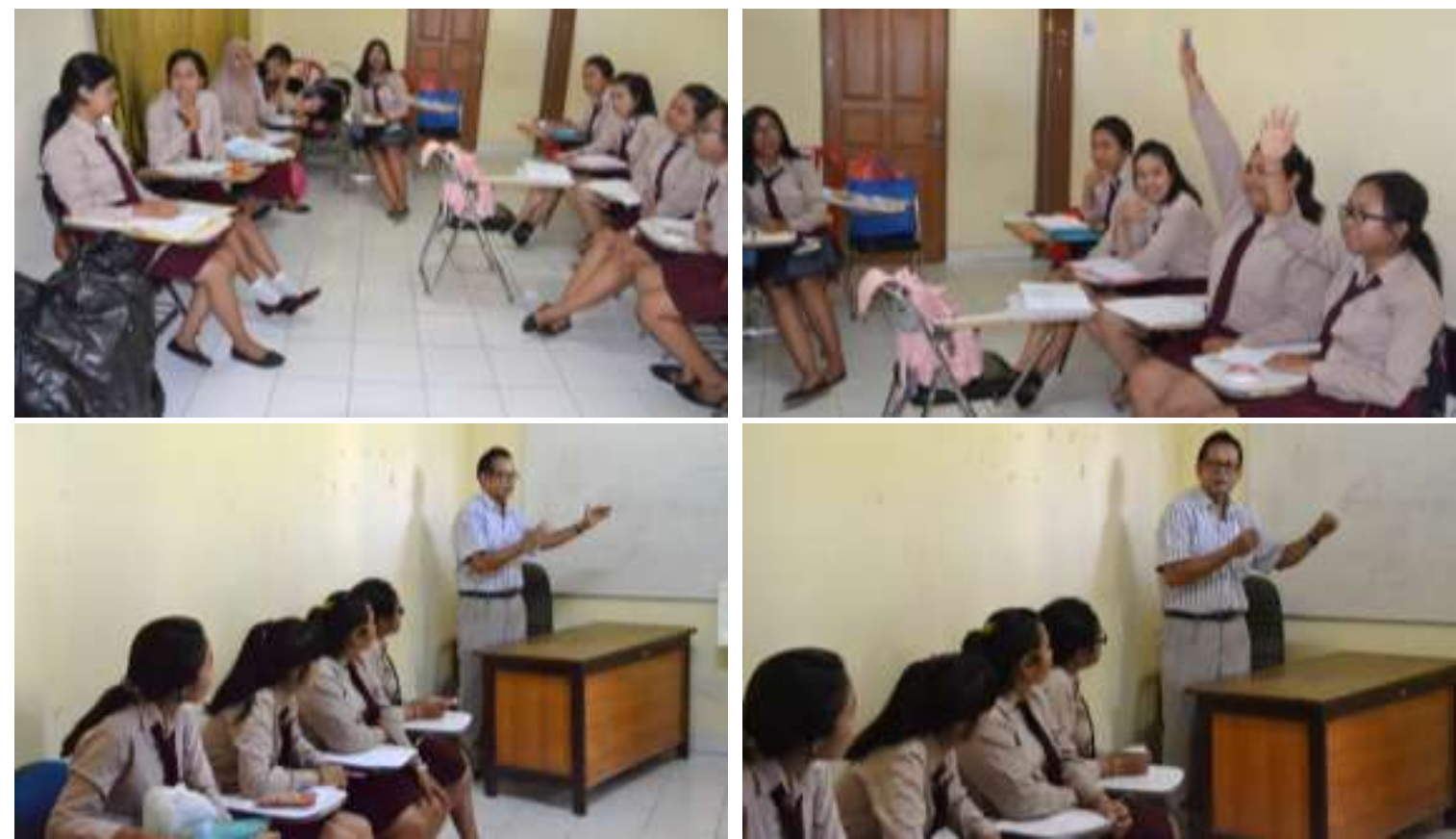

Gambar 3. Kegiatan berdiskusi, dengan saling memberikan saran serta melakukan diskusi balikan dengan pendekatan supervisi klinis antara mahasiswa dengan mahasiswa, mahasiswa dengan observer, dan mahasiswa dengan dosen pembimbing.

\section{HASIL DAN PEMBAHASAN}

Berdasarkan hasil penelitian dan analisis, didapatkan hasil yang menunjukkan adanya peningkatan keterampilan mengajar. Hal ini dibuktikan melalui penerapan model pembelajaran brainstorming dengan pendekatan supervisi klinis sebagai prosedur pelaksanaan memberikan kontribusi positif pada proses pembelajaran bagi mahasiswa yang bermuara pada peningkatan keterampilan mengajar.

Persentase rerata keterampilan dasar mengajar tiap siklus mengalami peningkatan secara positif. Pada tahap prasiklus rerata awal keterampilan mengajar hanya 80,56 yang artinya keterampilan dasar mengajar mahasiswa PGPAUD masih berada di kategori tinggi atau ada rentang nilai $B$. Peningkatan secara signifikan terjadi pada siklus I dengan menerapkan model pembelajaran brainstorming dengan hasil rerata menjadi 85,94 yang artinya keterampilan dasar mengajar mahasiswa PGPAUD sudah berada di kategori sangat tinggi atau ada pada rentang nilai $\mathrm{A}$, namun nilai tersebut masih berada di batas bawah kategori sangat tinggi, sehingga perlu ditingkatkan pada siklus II.

Pada siklus II, peningkatan terjadi dengan hasil rerata 86,50 yang menandakan bahwa penerapan model pembelajaran brainstorming dengan pendekatan supervisi klinis mampu meningkatkan keterampilan dasar mengajar mahasiswa PGPAUD dengan hasil sangat tinggi dan ada pada kategori nilai A. Untuk lebih jelasnya hasil penelitian ini dijabarkan pada grafik histogram berikut ini. 


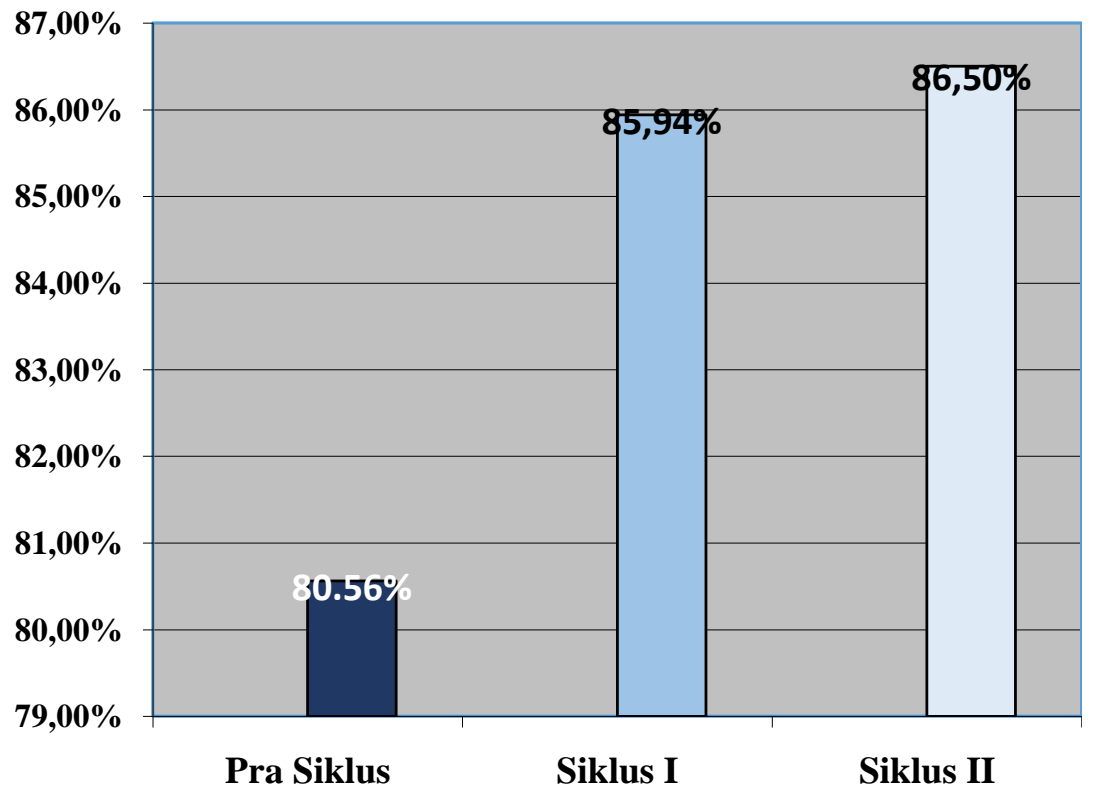

Gambar 4. Hasil keterampilan mengajar mahasiswa yang menerapkan pembelajaran

Dari hasil penelitian, dengan menggunakan metode penelitian yang telah disepakati diperoleh data bahwa melalui penerapan model pembelajaran brainstorming dengan pendekatan supervisi klinis, menunjukkan hasil peningkatan keterampilan mengajar pada mata kuliah micro teaching mahasiswa semester VI PGPAUD Undiksha Denpasar.

Peningkatan tersebut tidak dapat terlepas dari aktivitas mahasiswa dalam memberikan sumbang saran terhadap apa yang sudah baik dilakukan, apa yang perlu ditingkatkan dan hal-hal apa yang tidak boleh dilakukan. Masing-masing mahasiswa diberikan kesempatan untuk mengomentari penampilan rekannya melalui tahap refleksi yang dapat dipakai sebagai acuan untuk merencanakan kembali pembelajaran. Demikian juga tim peneliti sebagai observer mengamati dengan serius dan teliti tentang kelebihan dan kekurangan penampilan mahasiswa sebagai bahan untuk dikaji pada saat pelaksanaan diskusi ditahap refleksi.
Suasana dalam refleksi mencerminkan suatu keterbukaan baik dari mahasiswa maupun dosen pelaksana sebagai observer dengan satu komitmen mempersiapkan calon guru yang dapat memenuhi kompetensi guru, baik kompetensi pedagogik, professional, sosial dan personal.

Berkaitan dengan hasil penelitian ini, menunjukkan bahwa dengan melaksanakan pembelajaran dengan menerapkan model pembelajaran brianstroming dengan pendekatan supervisi klinis menunjukkan bahwa adanya peningkatan yang positif meningkatkan keterampilan mengajar mahasiswa PGPAUD semester VI.

Penelitian ini relevan dengan penelitian Margariena, Achmad Supriyanto, Burhanuddin yang termuat pada jurnal pendidikan dengan EISSN 2502-471X tahun 2016 dengan judul "Implementasi Supervisi Klinis Dalam Meningkatkan Efektivitas Pembelajaran Di Sekolah Dasar" dan penelitian tentang brainstorming oleh Ardian dan Riswan 
Dwi Djatmiko yang termuat pada jurnal pendidikan teknologi dan kejuruan dengan ISSN 18929-5797 tahun 2008 dengan judul "penerapan model pembelajaran brainstorming untuk meningkatkan kreativitas mahasiswa pada mata kuliah praktik Fabrikasi" dengan hasil terjadi peningkatan kreatifitas mahasiswa secara signifikan dari semula $55,02 \%$ menjadi $70,32 \%$ atau meningkat $15,3 \%$.

\section{SIMPULAN}

Berdasarkan hasil penelitian dan analisis dapat disimpulkan bahwa penerapan pembelajaran brainstorming dengan pendekatan supervisi klinis dapat meningkatkan keterampilan mengajar pada mata kuliah micro teaching mahasiswa semester VI PGPAUD Undiksha.

Hal ini dapat dibuktikan dengan hasil analisis yang menunjukkan bahwa terjadi peningkatan persentase rata-rata keterampilan dasar mengajar yang dari tahap prasiklus hanya $80,56 \%$ dan berada pada katagori tinggi, meningkat menjadi $85,94 \%$ atau peningkatannya sebesar $5,39 \%$. Peningkatan ini dipandang perlu dilanjutkan ke siklus II mengingat bahwa hasil penelitian di siklus I masih berada di dekat ambang batas bawah kategori sangat tinggi. Pada siklus II diperoleh peningkatan yang semula $85,94 \%$ menjadi $86,50 \%$. Tetapi dengan hasil persentase di siklus II yaitu $86,50 \%$, persentase tersebut sudah berada pada rentang kategori sangat tinggi dan jika dikonservasi pada skala nilai huruf berada pada nilai $\mathrm{A}$.

Berdasarkan hasil simpulan maka diharapkan hasil penelitian ini dapat memberikan kontribusi terhadap (1) pelaksanaan proses pembelajaran yang meningkat dengan menerapkan model pembelajaran brainstorming dengan pendekatan supervisi klinis, (2) model pembelajaran ini dapat memberikan kesempatan untuk mengeksplorasi seluruh saran yang membangun demi peningkatan hasil belajar dan pengalaman belajar mahasiswa.

\section{DAFTAR PUSTAKA}

Ardian dan Riswan, D.D. (2008). Penerapan Model Pembelajaran Brainstorming Untuk Meningkatkan Kreativitas Mahasiswa Pada Mata Kuliah Praktik Fabrikasi. Jakarta: Jurnal Pendidikan Teknologi dan Kejuruan UNY, dengan ISSN 189295797 vol.17, Mei 2008

Margariena., Achmad, S., Burhanuddin. (2016). Implementasi Supervisi Klinis Dalam Meningkatkan Efektivitas Pembelajaran Di Sekolah Dasar. Malang: Jurnal Pendidikan dengan EISSN 2502-471X tahun 2016 UNM

Sudrajat. (2008). Supervisi Klinis. diakses tanggal 6 April 2017 (Online tersedia pada https://akhmadsudrajat.wordpress.co $\mathrm{m} / 2008 / 03 / 01 /$ supervisiklinis/\#comments ,)

Suhartati. (2014). Penggunaan Supervisi Klinis Dalam Peningkatan Kemampuan Pembelajaran Tematik Guru Kelas Rendah. Jawa Tengah: Jurnal Penelitian Tindakan Sekolah dan Kepengawasan. Vol. 1, No. 1, Juni 2014

Sutikno, M. Sobry, dan Pupuh, F. (2007). Strategi Belajar Mengajar Melalui Penenaman Konsep \& Konsep Islami. Bandung : PT. Refika Aditama

Suyatno. (2009). Menjelajah Pembelajaran Inovatif. Surabaya: Mas Media Buana Pustaka. 